\title{
Readability of Conceptual Science Material Teaching based on Science Literacy Using Modified Cloze Test Technique to Develop Computational Thinking Skills
}

\author{
F. Fakhriyah \\ Primary Education Teacher \\ Departement \\ Universitas Muria Kudus \\ Kudus, Indonesia \\ fina.fakhriyah@umk.ac.id
}

\author{
S. Masfuah \\ Primary Education Teacher \\ Departement \\ Universitas Muria Kudus \\ Kudus, Indonesia \\ $\underline{\text { siti.masfuah@umk.ac.id }}$
}

\author{
M. Roysa \\ Primary Education Teacher \\ Departement \\ Universitas Muria Kudus \\ Kudus, Indonesia \\ mila.roysa@umk.ac.id
}

\begin{abstract}
This study aims to describe the level of legibility of science-based literacy materials to develop computational thinking skills in PGSD students of Muria Kudus University. The development of science literacy teaching materials have been done in stages, from expert validation of content material. Furthermore, the measurement of legibility is required. The level of legibility of the teaching materials is measured by the modified cloze test technique. Analyzing the readability score data is using Bormuth criteria. From the measurement results shows score $\mathbf{5 5 . 4}$ on the criteria can be understood and read in accordance with the students.
\end{abstract}

Keywords - Teaching Materials; Modified cloze test; Scientific Literacy; Computational Thinking Skills

\section{INTRODUCTION}

The development of science and technology in this 4.0 industrial revolution era demands higher education level to always develop and improve itself. Education is a basic activity to create better and competitive human sources both their reasoning and action. Primary educational teacher department is as a department training its in service teacher students will create the agents of change inviting their students to think critically, innovatively, be digital literate, and have artificial intelligence. To achieve those things, learning must be improved in higher education leading to competence and skill fulfillment needed by the candidates of teacher.

The development and improvement of curriculum content in higher education is needed. Beside science content, competence and skill must be had by the in service teacher students. The competence and skills to have are science literacy and computational thinking. Science literacy is related to someone's ability to understand and implement science into his daily life
[1], meanwhile computational thinking is a pattern to solve problem by interpreting ideas, data, logics from various knowledge and thought as if it was computer [2] Computational thinking should be owned by students because not all problems can be solved by just thinking critically, but must involve technology, logic, modeling, abstraction and constructive thinking [3]. The flow of computational thinking invites human to think critically, creatively through integral thinking so complex problem can be solved as if it was computer software. It is needed by teacher to explain more complex problems using abstracts, models, and stimulus [4].

By understanding science literacy and computational thinking can be the part of the students' reliability. It is due to science literacy is a competence to be mastered by the students and integrated into curriculum, purposes, concepts, science skills and other knowledge. When the students master science literacy, then they are expected to survive and solve problem in daily life [5] .Meanwhile, computational thinking is an ability of the students through activity to solve problems by using various knowledge they have. Good and Aman [6] states that CT is described as mental activity, a problem solving, an approach, a basic skill from various knowledge. CT can be maximal when the students also master science literacy, because computational thinking is a modernized science literacy. To measure the level of science literacy done by Fakhriyah, et al. [5] from the students shows $66.2 \%$ of them are in nominal level and $33.8 \%$ of them are in functional level. Based on the data, it is known that students having science literacy competence are still limited. The low level of science literacy competence is caused by the limitation of 
learning material provision to develop the literacy and skill. It is also confirmed by the questionnaire result of the preliminary study showing the students demanding to have better learning material to explore their ability by integrating various concepts, ideas, sources and phenomena.

Learning material is important to support learning process in the class. Learning material contributes to students' learning achievement because learning material contains the competence to achieve [7]. According to Patrick and Altbach [8], textbooks are instructional media centralizing the usage in educational system. Therefore, textbooks become the media of delivering curriculum [9]. Learning process using the learning material will last systematically and facilitate the students to understand the reviewed material. Based on the problem, then it is needed learning material development having science literacy to improve computational thinking.

Learning material based science literacy have been developed based on science conceptual content material needed by the students. Beside the synchronization of content material, learning material also can be used as learning source requiring readability of the material. Readability can be defined as a measurement of level of ease to understand a text. One of the requirements is must meet the level of readability [10] [11] [12]. Higher readability can be considered as the text is easy to understand, meanwhile lower readability means the text is difficult to understand [13]. Therefore, readability of learning material will determine the material understanding by the students. It is also strengthened by Burton [14] stating readability of learning material affecting significantly to students' ability to learn general Biology concept.

There are many ways to determine readability of learning material, subjective expert judgment, askinganswering method, readability formula (Fry graphic, SMOG, Fog, and Flesch), and cloze test. This study uses readability level measurement through cloze test. Cloze test is a method to acquire message from the sources, changing the pattern of the language and omitting some parts of the reading text to let the readers completing the whole information. The researcher uses cloze test readability level measurement because according to Slater and Thompson in Widodo [15] Fry graphic is not accurate to measure readability of science course textbooks, while the measurement of legibility with cloze test technique is not only concerned with aspects of vocabulary and sentence but also attention to aspects of concept difficulty because remembering the concept of science material is not only about reading material but it involves formulas, graphs and pictures. Therefore, the measurement uses modified cloze test technique to avoid different interpreting criteria of the different scores.
Based on the consideration, then the purpose of the research is to describe the measurement of readability level of learning material based on science literacy to develop computational thinking skills of the students to create appropriate learning material products in the courses of science literacy concepts. It is also purposed to develop their computational thinking skills.

\section{METHOD}

This study is the third part of research and development about the development of learning material with science literacy to improve CT. The study uses research and development approach of Samsudi [16] covering preliminary, development, and validation. This article provides the test results of readability of learning material which is the part of learning material validation. The stage covers revision of evaluation of the material from validators given to the students through massive trial. This type of research uses descriptive content analysis. The instrument used are readability test with modified cloze test. Readability test is given to 2C class PGSD students as an experimental class that takes the Science Concept course through large-scale trials, prior to the posttest.

The data of readability is learning material of Science Concept course to develop computational thinking by implementing modified cloze test. The test is given to the students after reading and joining the learning process. The test contains 50 omitted words systematically. The readability level is gained from all respondents. The criteria of readability of the learning material uses Bormuth's opinion [17] classifying as follows:

TABLE I. THE CRITERIA OF READABILITY OF LEARNING MATERIAL MEASUREMENT

\begin{tabular}{|l|l|}
\hline Score & Criteria \\
\hline$<37$ & $\begin{array}{l}\text { The learning material is difficult to } \\
\text { understand and not appropriate to the } \\
\text { students. }\end{array}$ \\
\hline $37-57$ & $\begin{array}{l}\text { The learning material is understandable } \\
\text { and appropriate to the students. }\end{array}$ \\
\hline$>57$ & $\begin{array}{l}\text { The learning material is understandable } \\
\text { and independently studied by the student. }\end{array}$ \\
\hline
\end{tabular}

\section{FINDING AND DISCUSSION}

The measurement of readability level of the material is a part of research and development, especially validation stage. The stage covers expert validation before limited scale trial run, then the revision of the expert continued by massive scale trial run using the measurement. Readability of all elements of the text (included interaction among text) affecting toward the success of the readers to understand compared to their reading speed [18]. 
The procedure of cloze test, known as omitted text test from the original learning material text, some words are omitted systematically with the purpose to find out the readability. The modified cloze test used in the measurement consists of 50 words being omitted into 12 paragraphs with 1053 word numbers. In the measurement of readability level of the learning material, the text used in the test is not original text of the learning material. The text is arranged by referring to the learning material about Movement System. The text used is a text with summarizing criteria. So far, the measurement of readability only uses cloze test used in language learning [19].

From the measurement data of readability of learning material with the text, here is the data.

TABLE II. THE READABILITY MEASUREMENT RESULTS OF THE LEARNING MATERIAL

\begin{tabular}{|c|c|c|c|}
\hline Num & $\begin{array}{c}\text { The } \\
\text { Proportion } \\
\text { of Correct } \\
\text { Answers }\end{array}$ & $\begin{array}{l}\text { The Level } \\
\text { of } \\
\text { Readability }\end{array}$ & $\begin{array}{c}\text { The Average } \\
\text { Score and } \\
\text { Criteria }\end{array}$ \\
\hline 1 & 19 & 48.7 & \multirow{32}{*}{$\begin{array}{c}55.4 \\
\text { With } \\
\text { understandable } \\
\text { criterion of the } \\
\text { learning } \\
\text { material and } \\
\text { appropriate for } \\
\text { the students }\end{array}$} \\
\hline 2 & 19 & 48.7 & \\
\hline 3 & 40 & 103 & \\
\hline 4 & 23 & 59 & \\
\hline 5 & 19 & 48.7 & \\
\hline 6 & 29 & 74.4 & \\
\hline 7 & 28 & 71.8 & \\
\hline 8 & 25 & 64.1 & \\
\hline 9 & 35 & 89.7 & \\
\hline 10 & 20 & 51.3 & \\
\hline 11 & 0 & 0 & \\
\hline 12 & 2 & 5.13 & \\
\hline 13 & 28 & 71,8 & \\
\hline 14 & 28 & 71,8 & \\
\hline 15 & 21 & 53.8 & \\
\hline 16 & 0 & 0 & \\
\hline 17 & 0 & 0 & \\
\hline 18 & 23 & 59 & \\
\hline 19 & 16 & 41 & \\
\hline 20 & 16 & 41 & \\
\hline 21 & 0 & 0 & \\
\hline 22 & 20 & 51.3 & \\
\hline 23 & 19 & 48.7 & \\
\hline 24 & 37 & 94.9 & \\
\hline 25 & 22 & 56.4 & \\
\hline 26 & 1 & 2.56 & \\
\hline 27 & 32 & 82.1 & \\
\hline 28 & 29 & 74.4 & \\
\hline 29 & 31 & 79.5 & \\
\hline 30 & 19 & 48.7 & \\
\hline 31 & 19 & 48.7 & \\
\hline 32 & 28 & 71.8 & \\
\hline
\end{tabular}

\begin{tabular}{|l|c|c|}
\hline 33 & 26 & 66.7 \\
\hline 34 & 29 & 74.4 \\
\hline 35 & 20 & 51.3 \\
\hline 36 & 4 & 10.3 \\
\hline 37 & 21 & 53.8 \\
\hline 38 & 29 & 74.4 \\
\hline 39 & 38 & 97.4 \\
\hline 40 & 35 & 89.7 \\
\hline 41 & 29 & 74.4 \\
\hline 42 & 27 & 69.2 \\
\hline 43 & 21 & 53.8 \\
\hline 44 & 28 & 71.8 \\
\hline 45 & 30 & 76.9 \\
\hline 46 & 25 & 64.1 \\
\hline 47 & 21 & 53.8 \\
\hline 48 & 22 & 56.4 \\
\hline 49 & 12 & 30.8 \\
\hline 50 & 16 & 41 \\
\hline
\end{tabular}

The table shows the average score of readability, 55.4, with understandable criterion and appropriate for the students. Indirectly, it can be understood that the student are able to read and understand anything written in the learning material. Teaching materials are at an instructional level [20]. This is because the content of this teaching material uses rhetorical questions that guide students to find concepts, avoid threatening sentences, be contextual and involve students actively in CT literacy discussion topics. At the beginning of learning, students first read about the context and content of science literacy, the phenomenon and application of science in everyday life. After that students are involved in the literacy phenomenon which contains questions that must be answered and discussed as the initial hypothesis. Furthermore, students do inquiry practicum, create reports, graphics, abstraction and solve problems in accordance with the flow of CT. Therefore, students are able to understand the material from the teaching materials well. Indirectly it can be interpreted that students are able to read and understand things written in teaching materials, although there are some parts that need to be clarified as a guide to readers to better understand the material. Inputs that need to be revised in teaching materials such as the existence of some foreign terms and the writing of scientific names and formulas and units that are not understood by students, so it takes a glossary, emphasizing the terms and index so that students better understand the material. With reference to legibility, vocabulary contributes to the fluency of reading [21] and vocabulary knowledge influences textual understanding [22].

Based on the initial needs analysis, students find it difficult to read and understand the subject matter of science because in addition to abstract conceptual presentation, the available literatures are mostly 
foreign languages or translations which they find difficult to understand. Montgomery [23] states that science having many technical terms and meaning, so many researchers from various fields having problems to communicate. Then, when the students learning science, they need to have technical terms translated appropriately to match their ability. It is also strengthened by Gallagher et al [24] stating teachers are the last line of text supervision to adjust learning needs. Instructionally, lecturers access various text and genres to relate content learning with literacy skills and technology. The result is the improvement in learning and ability to read, write, and discuss authentically. It is an integral part to learn science and science literacy.

The learning material developed is based on the analysis of needs and problems faced by the students. Ginting [25] states that the learning material is categorized well when the topic discussed is appropriate, having supportive information to understand the material, delivered in brief, simple, and systematic language so easy to understand, completed with illustration and relevant examples, and interesting to understand the learnt material. Then, the tendency on this learning material is science literacy and computational thinking. Science literacy becomes important because it is one of purposes of 21 century education [26]. Meanwhile, computational thinking is new science literacy is new literacy in the middle of 21 century [27]. The development of science literacy and computational thinking skills is needed because science literacy is a competence to implement science in everyday life, whereas computational thinking is the ability to actualize science literacy through various thinking activities. It is as the embodiment of students' readiness to face the growth of knowledge challenges and technology in 4.0 industrial revolution era. The problems appearing can be solve by critically, creatively involving computing thinking skill skills and thinking, with various ways of reasoning. Meanwhile, according to Nooris \& Phillips [28] stating that understanding, interpreting, analyzing, and discussing scientifically are the functions of science literacy.

Based on the discussion with the validators, the learning material has been already appropriate with the material content for higher education. It has covered all literacy competences and computational thinking. The learning material is presented with scientific phenomena content based science literacy and reasoning activity to solve problems through computational thinking. CT steps consist of analyzing and finding data, ideas, and facts in the story of science phenomena, elaborating the problems into more specific parts, creating abstract, creating algorithm by determining systematic problem solving, automatication on determining appropriate step, presenting the used steps by simulating and concluding [27]. The diction accuracy and material arrangement will influence readability level of the learning material. Furthermore, Gallagher et al [24] states that the background of the study and vocabulary are the most important components in science curriculum with rich literacy, and important to provide ways to improve the students' understanding.

The learning concept to improve the skills also shows visual figures to ease the students understanding the material, to find their own concept using science literacy and CT skills. It is supported by McTigue \& Croix [29] stating that visual readability is also an integral part of skills, and the students gain advantages from the instruction of direct understanding about how the elaboration and extraction of the meaning from the diagram or graphic in a science text. Especially, the word of the text can be supported by figures when the content or the vocabulary are challenging [30].

\section{CONCLUSION}

Based on the findings and discussion, the conclusion is - the measurement of readability level of science learning material to improve CT skills in Science Concept course gains score 55.4, with understandable and appropriate for the students criteria

\section{ACKNOWLEDGMENT}

Thanks to all parties helping, among them are the Dean of FKIP PGSD UMK, for allowing and supporting this research, Prof. Dr. Ani Rusilowati, M.Pd and Prof. Dr. Enni Suwarsi Rahayu, M.Si, as the team and partner of the researcher and also validators as well as Kemenristekdikti for its financial support upon this research.

\section{REFERENCES}

[1] Bybee, et al. (2009). "PISA 2006: An Assessment of Scientific Literacy". Journal of Research in Science Teaching. 46(8): 865-883.

[2] Qualls, J., A. \&Linda, B., S. (2010). "Why Computational Thinking Should Be Integrated Into The Curriculum". Journal of Computing Sciences in Colleges. 25(5): 66-71.

[3] Liu, J. \& Wang, L. (2010). Computational Thinking in Discrete Mathematics, IEEE 2nd International Workshop on Education Technology and Computer Science, 413-416.

[4] Voskoglou, M \& Sherly, B. (2012). "Problem Solving and Computers in a Learning Environment". Egyptian Computer Science Journal ECS. 36(4): 45-46.

[5] Fakhriyah, F. S. Masfuah, M. Roysa, A. Rusilowati, E. S. Rahayu. (2017). "Student's Science Literacy in the Aspect of Content Science?". Indonesian Journal of Science Education. 6(1): 81-87.

[6] Good, J. Aman Y. \& Punya. M. (2017). "Computational Thinking in Computer Science Classrooms: Viewpoints from CS Educators". Proceding Society for Information Technology \& 
Teacher Education International Conference. in Austin, TX, United States ISBN 978-1-93979727-8 Publisher: Association for the Advancement of Computing in Education (AACE), Chesapeake, VA. Retrieved from: http://www.punyamishra.com/wp content/uploads/2017/02/ComputationalThinking andCSTeachers.Good_.Yadav_.Mishra.pdf

[7] Bauer. (2010). "Textbooks and Teaching Resources: A Case Study from the Early Childhood Classroom-Australia". IARTEM eJournal. 3 (2): 81-96. Tersedia di http://www.biriwa.com/iartem/ejournal/archive.p hp [diunduh 5-5-2016]

[8] Patric, G. \& Altbach. (1991). Textbooks in American Society: Politics, Policy, and Pedagogy. Buffalo: Sunny Press.

[9] Abdulkarim, A. (2007). “Analisis Isi Buku Teks dan Implikasinya dalam Memberdayakan Keterampilan Berpikir Siswa SMA". Jurnal Forum Kependidikan. 26 (2). 118-131.

[10] Pranowo, D.D. (2011). Alat Ukur Keterbacaan Teks Berbahasa Indonesia. Laporan Penelitian tidak diterbitkan. Yogyakarta: FBSS Universitas Negeri Yogyakarta.

[11] Suherli, K. (2008). Pembelajaran Membaca Berbasis Teks Hasil Pengukuran Keterbacaan. Online at http://argumenapbi.blogspot.co.id/2009/02/pembelajaranmembaca-berbasis-teks.html. Diakses pada tanggal 24 Mei 2018.

[12] Sitepu, B.P. (2010). Keterbacaan. Online at https://bintangsitepu.wordpress.com/2010/09/11/ keterbacaan/. Diakses pada tanggal 24 Mei 2018.

[13] Harjasujana \& Mulyati. (1996). Membaca 2. Jakarta: Depdikbud.

[14] Rebecca, S. Burton. (2014). "Readability, Logodiversity, and the Effectiveness of College Science Textbooks". Bioscene. 40 (1). 3-10 online https://files.eric.ed.gov/fulltext/EJ1035554.pdf

[15] Tri Widodo, Antonius. (1995). Modifikasi Tes Rumpang untuk Bahan Ajar MIPA. Semarang: Lembar Penelitian UNNES.

[25] Ginting, P. \& Syafrizal H. S. (2008). Filsafat Ilmu dan Metode. Riset. USU Press. Medan.

[26] Holbrook \& Rannikmae. (2009). "The Meaning of Scientific Literacy". International Journal of Environmental \& Science Education. 4(3): 275$288 . \quad$ Retrieved from: www.ijese.com/IJESE_v4n3_Special_Issue_H olbrook.pdf.

[27] Wing, J., M. (2006). "Computational Thinking". Communication of the ACM. 49(3): 33-35.

[28] Norris S.P., \& Phillips, L.M. (2003). "How Literacy In Its Fundamental Sense Is Central to Scientific Literacy". Science Education. 87: 224-240.

[29] Mc. Tigue, Erin \& Amanda Croix. (2010). "Visual Literacy in Science". Online at https://www.researchgate.net/publication/2580 21975_Visual_Literacy_in_Science.

[30] Yore, L. D., Hand, B. M., \& Florence, M. K. (2004). "Scientists' views of Science, Models of Writing, and Science Writing Practices". Journal of Research in Science Teaching. 41(4), 338-369. doi:10.1002/tea.20008
[16] Samsudi. (2006). Desain Penelitian Pendidikan. Semarang: Universitas Negeri Semarang

[17] Tri Widodo, Antonius. (1993). Tingkat Keterbacaan Teks: Suatu Evaluasi terhadap Buku Teks Ilmu Kimia Kelas I Sekolah Menengah Atas: Disertasi. Jakarta: IKIP Jakarta.

[18] Nurdiyana, M.S., I Ketut M. \& Alex H. (2016). Keterbacaan dan Kelayakan Isi Modul Elastisitas dan Hukum Hooke Berbasis Multirepresentasi untuk SLTA Kelas X. Prosiding Seminar Nasional Pendidikan 2016.ISSN: 2527-5917 Vol Online https://media.neliti.com/media/publications/1163 86-ID-keterbacaan-dan-kelayakan-isi-modulelas.pdf. Diunduh tanggal 26 Mei 2018.

[19] Habibian, Maryam. (2012). "The Investigation of Reading Comprrehension Test and Cloze Test Among Learners Who Learn English As A Foreign Languange With Respect to Their Language Proficiency and Gender". Journal of Social Science and Humanities. 7 (1); 177-186. Online http://ejournal.ukm.my/ebangi/article/viewFile/11 272/3659. Diakses pada 25 Mei 2018.

[20] Hardjasujana, Ahmad S. dan Yeti Mulyati. 1996. Membaca 2. Jakarta: Depdikbud

[21] Graves, M.F. (2006). The Vocabulary book: Learning and Instruction. New York, NY: Teachers College Press.

[22] Bravo, M., \& Cervetti, G. (2008). Teaching vocabulary through text and experience in content areas. In A. E. Farstrup \& S. J. Samuels (Eds.), What research has to say about vocabulary instruction (pp. 130-149). Newark, DE: International Reading Association.

[23] Montgomery, S. (2004). Of Towers, Walls, and Fields: Perspectives on Language in Science. Science. 303: 1333-1335.

[24] Gallagher, T. Xavier F. Katia, C. (2017). "A Comparison of Readability ini Science-Based Texts: Implications for Elementary Teachers". Canadian Journal of Education. 40(1). 1-29. 